\title{
Neuropharmacological Profile of Extracts of Aerial Parts of Convolvulus pluricaulis Choisy in Mice Model
}

\author{
Nasir A. Siddiqui ${ }^{1}$, Nihal Ahmad $^{2}$, Nazia Musthaq ${ }^{3}$, Ipshita Chattopadhyaya ${ }^{3}$, Rachna Kumria ${ }^{4}$ and \\ Sumeet Gupta*,3 \\ ${ }^{I}$ Department of Pharmacognosy, College of Pharmacy, King Saud University, Riyadh, Kingdom of Saudi Arabia \\ ${ }^{2}$ Department of Forensic Medicine and Toxicology, K.M.C.T. Medical College, Manassery, Mukkam, Kerala-673602, \\ India \\ ${ }^{3}$ Department of Pharmaceutical Sciences, M.M. College of Pharmacy, M.M. University, Mullana, Ambala, Haryana, \\ India \\ ${ }^{4}$ Department of Pharmaceutical Sciences, Swift College of Pharmacy, Rajpura Punjab
}

\begin{abstract}
The plant of Convolvulus pluricaulis Choisy was found to be used by different traditional systems and folklore for the treatment of various disorders. The aim of the present study was to investigate the neuropharmacological activity of various extracts of Convolvulus pluricaulis Choisy in albino mice. The animal behavior was evaluated by locomotor activity, tremors activity, sleep inducing model and anxiolytic activity using standard procedures in experimental animal models. The results revealed that ethanolic and aqueous extract showed promising results in terms of statistical manner when compared with control group. In conclusion, this plant exhibits neuorpharmacological activity in tested animals.
\end{abstract}

Keywords: Ayurvedic system, mice, neurobehavioral, shankhpushpi.

\section{INTRODUCTION}

Neurological disorders pose an intellectual challenge to the physicians to make the correct neurological diagnosis. Drugs acting on central nervous system (CNS) were among the first to be discovered by primitive human and are still the most widely used group of pharmacological agents. The drugs acting on CNS are therapeutically invaluable as they can produce specific physiological and psychological effects. Modern medicine offers symptomatic treatment that is often expensive and associated with side effects. Indian system of medicine has traditionally been used in several neurological conditions like Alzheimer, Epilepsy, Parkinsonism, and Schizophrenia [1]. From the vast array of materia medica of the indigenous system, many plants have been reported to have activity against CNS disorders and act as very useful remedies for the alleviation of human suffering [2]. Convolvulus is a genus of about 250 species of flowering plants belonging to family convolvulaceae and it has cosmopolitan distribution. Convolvulus pluricaulis Choisy (Convolvulaceae) syn Convolvulus microphyllus Sieb. ex Spreng commonly called as Shankpushpi. It is widely used in Unani medicine and ancient system of medicine. It is also in the list of Ayurvedic Pharmacopeia of India [3]. The plant

\footnotetext{
*Address correspondence to this author at the Department of Pharmacology, M. M. College of Pharmacy, M. M. University, Mullana, Ambala, Haryana133203, India; Tel: 09872620252, 08059930156; Fax: 01731304100; E-mail: sumeetgupta25@gmail.com
}

and plant parts reported various pharmacological activities like brain tonic, anticonvulsant, nervine tonic, aphrodisiac, anti-inflammatory, antitussive, eye tonic, blood purifier, antioxidant, antibacterial, antifungal, neuroprotective, antidiabetic, antihypertensive, antiulcers and hypolipideimic activity. Another studies reported on the basis of traditional uses like nootropic, anti-stress, anxiolytic, antidepressant, anticonvulsant, tranquilizing and sedative properties. Ethyl acetate and aqueous fractions of the ethanolic extract of this plant were both found to significantly improve learning and memory in active and passive avoidance models [4]. Based on the background, the present investigation was undertaken to study neuropharmacological profile of various extracts of aerial parts of Convolvulus pluricaulis Choisy on mice model.

\section{MATERIALS AND METHODS}

\section{Plant Material}

Aerial parts of Convolvulus pluricaulis Choisy was procured from National Drugs and Botanicals, Sahibabad, Ghaziabad, Uttar Pradesh and was identified with the help of literature and authenticated by a taxonomist, Prof. M.P. Sharma, Department of Environmental Botany, Hamdard University, New Delhi. The voucher specimen is retained in Phytochemistry Research Laboratory, Hamdard University, New Delhi. The fresh plant material was cleaned with distilled water and dried at $35^{\circ}-40^{\circ} \mathrm{C}$ for 10 days and, 
pulverized in electric grinder and the powder was passed through sieve No. 60 and used for further extraction.

\section{Preparation of Extracts}

The dried powder of aerial parts $(1 \mathrm{~kg})$ was successively soxhlet extracted using chloroform and ethanol $\left(60-80^{\circ} \mathrm{C}\right)$ for $72 \mathrm{hrs}$ each. Crude aqueous extracts of aerial parts $(1 \mathrm{~kg})$ were prepared separately by maceration for $72 \mathrm{hrs}$. The last trace of solvent is removed by reduced pressure distillation and then vacuum dried. The extract was stored below $4^{\circ} \mathrm{C}$ until further used. When needed, the extract was suspended/ dissolved in desired solvent and use. The extracts were concentrated by performing the qualitative chemical tests to determine the presence of sterols, phenol compounds, flavonoids, tannins, alkaloids, glycosides, triterpenoids and saponins, respectively.

\section{Animals}

Adult swiss albino mice of either sex weighing about $30-50 \mathrm{gm}$ were used with the approval of the institute animal ethics committee (453/01/a/CPCSEA). The animals were housed under standard conditions of temperature $\left(24 \pm 28^{\circ} \mathrm{C}\right)$ and relative humidity (60-70\%) with a 12:12 light-dark cycle. The animals were fed with standard pellet diet (Lipton India, Ltd) and water ad-libitum.

\section{Drugs and Dosage}

Extracts was administered orally at doses $(500 \mathrm{mg} / \mathrm{kg})$ in the form of suspension prepared in $0.2 \mathrm{ml}$ of $2 \% \mathrm{w} / \mathrm{v}$ Carboxy methyl cellulose with $2.0 \%$ Tween 80 . Diazepam (1 $\mathrm{mg} / \mathrm{kg})$, Amphetamine injection $(2 \mathrm{mg} / \mathrm{kg})$, Thiopental sodium injection $(40 \mathrm{mg} / \mathrm{kg})$ were prepared.

\section{EXPERIMENTAL DESIGN}

\section{Thiopental Sodium Induced Sleeping Time Test [5]}

The animals were randomly divided into five groups consisting of six mice each. The test groups received chloroform, ethanol and aqueous extract orally from the aerial parts of Convolvulus pluricaulis Choisy at doses of $500 \mathrm{mg} / \mathrm{kg}$ of body weight while the positive control was treated with diazepam $(1 \mathrm{mg} / \mathrm{kg})$ and normal control treated with (1\% Tween 80 in water). Thirty minutes later, thiopental sodium $(40 \mathrm{mg} / \mathrm{kg}$ ) was administered to each mouse of all groups except normal control to induce sleep. The animals were observed for the latent period (time between thiopental administrations to loss of righting reflex) and duration of sleep i.e. time between the loss and recovery of righting reflex.

\section{Pentylenetetrazol-induced Seizures [6]}

The extracts was administered orally at a doses of $500 \mathrm{mg} / \mathrm{kg}$ bodyweight $30 \mathrm{~min}$ before the subcutaneous injection of PTZ $(80 \mathrm{mg} / \mathrm{kg})$ and mice were observed for onset of clonic convulsions. One group received vehicle while other group received diazepam $(2.0 \mathrm{mg} / \mathrm{kg}$, i.p. $)$ as a reference standard. The animals were observed for onset of convulsion upto 30 min after PTZ.

\section{Anti Anxiety [7]}

Elevated plus maze (EPM) test (Pellow et al., 1985) for studying the anxiolytic effect in mice was used. EPM consists of two open arms $(15 \times 10 \mathrm{~cm})$ and two closed arms $(50 \times 10 \times 40 \mathrm{~cm})$ with an open roof elevated at $50 \mathrm{~cm} .1 \mathrm{~h}$ after the oral administration of different extracts at a dose of $500 \mathrm{mg} / \mathrm{kg}$ bodyweight, the mice was placed at the centre of the maze, facing one closed arm. During a 5 min test period the following measures were taken: the time spent in the open and closed arms; and total number of arm entries.

\section{Locomotor Activity [8]}

The locomotor activity was measured using an actophotometer. Movement of the animal cuts off a beam of light falling on the photocell and a count was recorded and displayed digitally. The total readings for 5 minutes give a measure of the spontaneous motor activity. In all behavioral experiments, in order to remove odors, the apparatus was cleaned with 5\% ethanol solution after each test. Each mice was tested individually and only once.

\section{Statistical Analysis}

The data were expressed as mean \pm SEM. The statistical significance between means was analyzed using one-way analysis of variance (ANOVA) followed by Tukey's multiple comparison test. A $\mathrm{p}<0.005$ was considered as statistically significant.

\section{RESULTS}

\section{Preliminary Phytochemical Screening Test}

The result of qualitative analysis indicated that extracts of aerial parts of Convolvulus pluricaulis Choisy possess sterols, tannins, triterpenoids, flavonoids, alkaloids, saponins glycosides and carbohydrates. Ethanolic and aqueous extracts of $C$. pluricaulis showed statistical significant $(p<0.001)$ potentiation of sleeping time while the chloroform extract did not show any significant potentiation for the same (Table 1). Ethanolic, chloroform and aqueous extract of C. pluricaulis showed highly statistical significant $(\mathrm{p}<0.001)$ protection against the PTZ induced clonic convulsions while the standard treated groups showed totally absent in any convulsion (Table 2). Ethanolic and chloroform extract treated mice had spent significant time in open arms which showed statistical significant anxiolytic type of effect but aqueous extract (Table 3) showed lesser significant effect $(\mathrm{p}<0.05)$ when compared to control group. In locomotor activity, only two extracts (Ethanolic and aqueous) showed the antagonist effect of amphetamine on mice and also revealed a good response in touch and sound activity (Table 4).

\section{DISCUSSION}

Mental, neurological and behavioral disorders are common to all countries and cause immense suffering. People with these disorders are often subjected to social isolation, poor quality of life and increased mortality. These disorders are the cause of staggering economic and social costs. Habituation, dependence and the resulting potential for 
Table 1. Effect of aerial parts of Convolvulus pluricaulis Choisy on thiopental sodium-induced sleeping time in mice.

\begin{tabular}{|c|c|c|c|}
\hline S. No & Groups & Doses & Onset of Sleep (Minutes) \\
\hline \hline 1 & Normal control & $(1 \%$ Tween 80 in water) & $48.2 \pm 5.19$ \\
\hline 2 & Positive control (Thiopental sodium) & $40 \mathrm{mg} / \mathrm{kg}$ & $32.4 \pm 4.98$ \\
\hline 3 & Diseased +Ethanolic & $500 \mathrm{mg} / \mathrm{kg}$ & $88.8 \pm 5.1^{* * *}$ \\
\hline 4 & Diseased +Aqueous & $500 \mathrm{mg} / \mathrm{kg}$ & $67.2 \pm 6.66^{* * *}$ \\
\hline 5 & Diseased +Chloroform & $500 \mathrm{mg} / \mathrm{kg}$ & $44.6 \pm 6.82^{\mathrm{ns}}$ \\
\hline
\end{tabular}

Table 2. Effect of aerial parts of Convolvulus pluricaulis Choisy on Pentylenetetrazol-induced seizures in mice.

\begin{tabular}{|c|c|c|c|}
\hline S. No & Groups & Doses & Onset of Clonic Convulsions in Seconds \\
\hline 1 & Positive Control & ( $1 \%$ Tween 80 in water) & $90.5 \pm 16.3$ \\
\hline 2 & Diseased + Standard (Diazepam) & $(1 \mathrm{mg} / \mathrm{kg})$ & 0 \\
\hline 3 & Diseased +Ethanolic & $500 \mathrm{mg} / \mathrm{kg}$ & $453.5 \pm 32.5 * * *$ \\
\hline 4 & Diseased +Aqueous & $500 \mathrm{mg} / \mathrm{kg}$ & $673.8 \pm 41.36^{* * *}$ \\
\hline 5 & Diseased + Chloroform & $500 \mathrm{mg} / \mathrm{kg}$ & $544.1 \pm 28.12 * * *$ \\
\hline
\end{tabular}

Table 3. Anxiolytic effect of aerial parts of Convolvulus pluricaulis Choisy on mice model.

\begin{tabular}{|c|c|c|c|}
\hline S. No & Groups & Dose & Time Spent in Open Arms (Seconds) \\
\hline \hline 1 & Control & $(1 \%$ Tween 80 in water) & $23.4 \pm 5.3$ \\
\hline 2 & Diseased + Standard (Diazepam) & $(1 \mathrm{mg} / \mathrm{kg})$ & $156.6 \pm 32.8$ \\
\hline 3 & Diseased +Ethanolic & $500 \mathrm{mg} / \mathrm{kg}$ & $84 \pm 12.5 * * *$ \\
\hline 4 & Diseased +Aqueous & $500 \mathrm{mg} / \mathrm{kg}$ & $56.4 \pm 11.4 *$ \\
\hline 5 & Diseased +Chloroform & $500 \mathrm{mg} / \mathrm{kg}$ & $89.4 \pm 17.82^{* * * *}$ \\
\hline
\end{tabular}

Table 4. Effect of aerial parts of Convolvulus pluricaulis Choisy on locomotor activity in mice.

\begin{tabular}{|c|c|c|c|c|c|}
\hline S. No & Groups & Dose & Spontaneous Motor Activity & Sound Response & Touch Response \\
\hline \hline 1 & Normal Control & $(1 \%$ Tween 80 in water $)$ & $45.4 \pm 3.6$ & 3 & 6 \\
\hline 2 & Positive control (Amphetamine) & $(2 \mathrm{mg} / \mathrm{kg})$ & $567.3 \pm 45.7$ & 16 & 7 \\
\hline 3 & Diseased + Ethanolic & $500 \mathrm{mg} / \mathrm{kg}$ & $234.4 \pm 33.2^{* * *}$ & 6 & 10 \\
\hline 4 & Diseased + Aqueous & $500 \mathrm{mg} / \mathrm{kg}$ & $213.56 \pm 23.6^{* * *}$ & 14 & 3 \\
\hline 5 & Diseased+Chloroform & $500 \mathrm{mg} / \mathrm{kg}$ & $511.33 \pm 53.23^{\text {ns }}$ & 11 \\
\hline
\end{tabular}

addiction are the greater disadvantages of the modern synthetic psychopharmacological agents [9].

Preliminary chemical investigations revealed that the presence of flavonoids, alkaloids, triterpinoids and saponins in this plant were confirmed by our study. There is a large number of chemical compounds present in the plant endowed neuropharmacological activity and supported the traditional uses. Convolvulus pluricaulis reported various chemical constituents which include alkaloid shankhpushpine, the tropane alkaloids convolamine and scopoletin, ceryl alcohol, the flavonoid kaempferol and the steroids phytosterol and $\beta$-sitosterol [10].

On the basis of literature an attempt was made for the first time to study the neuropharmacological profile on aerial parts of Convolvulus pluricaulis Choisy. In the present study, among different extracts, ethanolic and aqueous extracts showed promising results in general behaviour models whereas chloroform extracts could not show any significant effect in thiopental sodium induced sleeping. In PTZ model, all three extracts showed remarkable $(\mathrm{p}<0.001)$ results as 
anticonvulsant activity whereas previous studies were also reported of various extracts of this plant possess reduction in tonic convulsions in different animal models [10,11]. Oral administration of ethanol and chloroform extracts at $500 \mathrm{mg} / \mathrm{kg}$ revealed significantly increased the total time spent in the open arms compared with that of vehicle treated group which indicated the anxiolytic like effect of drug and further, the results are quite comparable to diazepam $(1 \mathrm{mg} / \mathrm{kg})$ which are the standard anxiolytic drug, same results were noticed by other researcher who claimed and reported anxiolytic activity with different extracts of petal of Convolvulus pluricaulis Choisy [8]. In case of locomotor activity, ethanol and aqueous $(500 \mathrm{mg} / \mathrm{kg})$ extracts showed significantly reduced motor activity when compared with positive control group similar results were also reported by other researcher whereas chloroform extracts couldn't showed significant effect in reducing motor activity which was also reported by Dhingra et al., 2007 [3]. The probable mechanism through GABA-A-benzodiazepine receptors which are the most abundant inhibitory receptor system in the CNS and binding of a benzodiazepine agonist to its recognition site results in increased chloride ion flux which in turn hyperpolarizes the postsynaptic membrane at a level below that at which spike generation is possible and for this reason some GABA A agonists are frequently used for their hypnotic effects $[12,13]$. The compounds identified from the aerial parts of Convolvulus pluricaulisy Choisy contain shankhpushpine and several other compounds like scopoletin, ceryl alcohol, the flavonoid kaempferol and the steroids phytosterol and $\beta$-sitosterol, act as GABA-A agonists and this agonistic property could be attributed to the CNS depressant effect of Convolvulus pluricaulisy Choisy although there is no consensus about which substances are exactly responsible for these effects. However, further studies are necessary to evaluate the contribution of other substances that are isolated for the activity observed, because it still remains to be determined which components exactly were responsible for these effects.

\section{CONCLUSION}

From this study, aerial parts of Convolvulus pluricaulisy Choisy posses neuroprotectivity in mice model. However, further investigations are required to isolate the phytocon- stituents responsible for behavioral activity and to find their mechanism of action.

\section{CONFLICT OF INTEREST}

The authors confirm that this article content has no conflict of interest.

\section{ACKNOWLEDGEMENTS}

The authors are grateful to the Research Centre, College of Pharmacy, King Saud University, Riyadh, Kingdom of Saudi Arabia for the support in this research work.

\section{REFERENCES}

[1] Simonian, NA, Coyle JT. Oxidative stress in neurodegenerative diseases. Annu Rev Pharmacol Toxicol 1996; 36: 83-106.

[2] SubaV, Murugesan T, Rao RB, Pal M, Mandal SC, Saha BP. Neuropharmacological profile of Barleria lupulina Lindl. Extract in animal models. J Ethnopharmacol 2002; 81: 251-5.

[3] Dhingra D, Valecha R. Screening for antidepressant-like activity of Convolvulus pluricaulis Choisy in mice. Pharmacol Online 2007; 1: 262-78.

[4] Sethiya NK, Nahata A, Mishra SH, Dixit VK. An update on shankhpushpi, a cognition-boosting ayurvedic medicine. Chin J Integr Med 2009; 7: 1001-1022.

[5] Nataranjan B, Muralidharan A, Satish R, Dhananjayan R. Neuropharmacological activity of Trigonella foenum graecum Linn. Seeds. J Nat Remedies 2007; 7: 160-5.

[6] Ambawade SD, Kasture VS, Kasture SB. Anti convulsant activity of roots and rhizomes of Glycyrrhiza glabra. Ind J Pharmacol 2002; 34: 251-5.

[7] Nahata A, Patil UK, Dixit, VK. Anxiolytic activity of Evolvulus alsinoides and Convolvulus pluricaulis in rodents. Pharm Biol 2009; 47: 444-51.

[8] Sharma K, Arora V, Rana AC, Bhatnagar M. Anxiolytic effect of Convolvulus pluricaulis Choisy petals on elevated plus maze model of anxiety in mice. J Herbal Med Toxicol 2009; 3: 41-6.

[9] Neeraj K, Sethiya SH. Mishra. Review on ethnomedicinal uses and phytopharmacology of memory boosting herb Convolvulus pluricaulis Choisy. Aust J Med Herbal 2010; 22: 19-26.

[10] Ahmad S, Zafar RU, Sahid M. Anti convulsant potential of callus cultures of Convolvulus microphyllus Sieb. OPEM 2007; 7: 46-50.

[11] Sharma VN, Barar FS, Khanna NK. Some pharmacological actions of Convolvulus pluricaulis chois: an Indian indigenous herb. II. Indian J Med Res 1965; 53: 871-876.

[12] Seighart W. GABAA receptors: ligand-gated $\mathrm{Cl}$ - ion channels modulated by multiple drug binding sites. Trends Pharmacol Sci 1992; 13: 446-50.

[13] Stahl, S.M. Essential psychopharmacology online: neuroscientific basis and practical applications, $3^{\text {rd }}$ ed. New Delhi: Cambridge University Press; 2000 ISBN: 9780511447990. 